\title{
Hair Cortisol Concentration as a Biomarker of Sleep Quality and Related Disorders
}

\author{
Nisrin El Mlili 1,2,+, Hanan Ahabrach 1,2,+ and Omar Cauli 3,4,5,*(D) \\ 1 Higher Institute of Nursing Professions and Health Techniques (ISPITS), 93000 Tetouan, Morocco; \\ bioniss@hotmail.com (N.E.M.); hananahabrach@yahoo.fr (H.A.) \\ 2 Department of Biology and Health, Faculty of Sciences, University Abdelmalek Essâadi, \\ 93000 Tetouan, Morocco \\ 3 Department of Nursing, University of Valencia, 46010 Valencia, Spain \\ 4 Frailty and Cognitive Impairment Group (FROG), University of Valencia, 46010 Valencia, Spain \\ 5 Chair of Healthy, Active and Participatory Aging, Valencia City Council, University of Valencia, \\ 46010 Valencia, Spain \\ * Correspondence: Omar.Cauli@uv.es \\ + These authors contributed equally to this work.
}

check for updates

Citation: El Mlili, N.; Ahabrach, H.; Cauli, O. Hair Cortisol Concentration as a Biomarker of Sleep Quality and Related Disorders. Life 2021, 11, 81. https://doi.org/10.3390/life11020081

Academic Editor: Luca Steardo

Received: 11 January 2021

Accepted: 21 January 2021

Published: 22 January 2021

Publisher's Note: MDPI stays neutral with regard to jurisdictional claims in published maps and institutional affiliations.

\section{Copyright: (c) 2021 by the authors.} Licensee MDPI, Basel, Switzerland. This article is an open access article distributed under the terms and conditions of the Creative Commons Attribution (CC BY) license (https:// creativecommons.org/licenses/by/ $4.0 /)$.

\begin{abstract}
Cortisol is the end product of the hypothalamic-pituitary-adrenal (HPA) axis, and its production is increased mainly in stressful situations or in chronic disorders accompanied by stress enhancement. Altered cortisol concentrations have been reported in a number of neuropsychiatric diseases and sleep disorders. Cortisol concentrations have been measured using several methods, and in several matrixes, such as blood, saliva, and urine. However, lately, hair cortisol, for several reasons, has emerged as a promising biomarker of long-term retrospective HPA activation. Several experimental approaches for cortisol measurement with the corresponding concentration reference ranges and a summary of findings from scientific literature on this field are presented. There is evidence of a close relationship between HPA functional alteration and the development of neuropsychiatric disorders. Sleep disorders are the most common manifestation in several neuropsychiatric conditions, and have also been associated to cortisol alterations in both adults and children. Many studies indicate that hair cortisol constitutes a valuable tool for further contributing to existing data on salivary, plasma, or urinary cortisol concentrations in patients with sleep disorders.
\end{abstract}

Keywords: children; insomnia; REM sleep; circadian rhythm; shift work

\section{Introduction}

Cortisol is the end product of the hypothalamic-pituitary-adrenal (HPA) axis. It is mainly secreted in reaction to stress, and plays a key role in normal physiology [1-3]. Alterations of the HPA axis and cortisol concentrations have been related to the pathophysiology of a number of diseases, including neuropsychiatric disorders [4-6]. The two most widely known disorders due to alterations of the HPA axis, namely Cushing's syndrome (CS) (chronic hypercortisolemia) and Addison's syndrome (AS) (chronic hypocortisolemia), have been reported to exhibit certain neuropsychiatric manifestations-even if not too frequently—such as depression, sleep disorders, and cognitive impairment [4,5,7-10]. In CS patients with depression and anxiety, the treatment of hypercortisolemia has been found to induce a significant decrease in the psychopathological symptoms. These results suggest a relationship between elevated cortisol and psychopathological disorders [11].

In fact, altered cortisol concentrations have been reported in a number of diseases of the central nervous system, such as psychiatric disorders, e.g., posttraumatic stress disorder [12-14], schizophrenia [15], depression [16-19], anxiety [20-22], and cognitive impairment [23-25]. Changes in the peripheral levels of cortisol have also been reported in certain neurodegenerative conditions, such as Huntington's disease [26] or Alzheimer's disease [27]. Sleep disorders are a group of conditions that affect the ability to sleep well on 
a regular basis, whether they are caused by a health problem or by too much stress, sleep disorders are becoming increasingly common and cortisol alterations have been linked to sleep disorders [28-31].

In addition, sleep disorders are the most common manifestation in several neuropsychiatric diseases [32-34] and in many other disease conditions [35,36]. Sleep disorders have been associated to alterations of the HPA axis, and cortisol levels have been correlated to several aspects of sleep disorders in patients $[35,36]$.

Glucocorticoids are commonly used as stress biomarkers. In this regard, cortisol is the most common glucocorticoid in humans, in many mammals and in non-human primates, while in other vertebrates, such as rodents, corticosterone is the main stress hormone [1]. Although the role of cortisol in stress processes in both animals and humans is well known, data on its ability to reflect stress levels over long periods of time have been limited. This is largely due to the traditional criteria used for sample selection. Until recently, most studies investigated cortisol response from samples of saliva, serum, or urine. Both saliva and serum provide a measure of cortisol concentration at a very specific timepoint. Such samples therefore can be used to test for acute changes, but both techniques are subject to large daily physiological fluctuations-meaning that full assessment of prolonged systemic exposure to cortisol is extremely difficult. In healthy individuals, cortisol levels peak in the morning, and gradually decrease in the course of the day.

A single measurement in blood or saliva thus cannot fully reflect systemic exposure. The only solution is to obtain multiple samples throughout the waking period of the individual. Although cortisol determination in saliva has undeniable advantages over plasma, as it is a noninvasive method that does not generate additional stress, research using this method suggests that its relevance as a biological marker is applicable more to acute stress situations than to chronic processes [37]. For example, cortisol in saliva exhibited homogeneous increases in a sample of students before an oral examination, but not before a written examination [38]. However, the detection period is only $24 \mathrm{~h}$, and the analysis of serum cortisol, in addition to having the same time limitations, involves an invasive technique, which in itself can cause stress-thus modifying the amount of cortisol and giving rise to an increased number of false positive results. On the other hand, plasma or serum cortisol reflects the amounts of total cortisol and not free cortisol, which is the biologically active form of the molecule [38]. For these reasons, the cortisol level in blood or urine is primarily used to diagnose Cushing's syndrome or Addison's disease, both of which affect the production of cortisol by the adrenal glands and the corresponding increase in cortisol concentration in urine in these endocrinology disorders are observed at any time of the day and usually lack of daily rhythm. Plasma and saliva are point samples, while urine allows the detection of recent HPA activity over a period of a few hours (24-36 h). Furthermore, cortisol concentrations in these matrixes are influenced by circadian rhythmicity or other factors that induce short-term elevations in activity of the HPA axis $[39,40]$.

Hypercortisolism, hypocortisolism, and a blunted diurnal cortisol slope have all been associated with adverse measures of mental and physical health [1]. There is a high correlation between salivary cortisol levels and unbound cortisol in plasma and serum, which remains high during the circadian cycle and under different dynamic tests, such as adrenocorticotropic hormone $(\mathrm{ACTH})$ stimulation $[39,40]$. Since free cortisol represents the biologically active hormone fraction, salivary cortisol measures have early been considered as a better method than serum cortisol for the evaluation of adrenocortical function; however, cortisol measurement in blood and saliva samples should be performed at different timepoints within the same day because of cortisol circadian rhythm, and it is recommended to repeat cortisol measurements in blood and saliva samples in different days since many factors can acutely influence cortisol secretion [23-25,39,40]. The role of hypercortisolemia in the pathophysiology of sleep disorders and neuro-psychiatric disorders accompanied by sleep alterations can only be demonstrated through measures that reflect prolonged exposure to cortisol, since such disorders are typically chronic conditions. 
Hair analysis has been used for decades to monitor exposure to exogenous substances in forensic science and toxicology [41]. Hair is therefore valued for its ability to reflect long periods of time with retrospective information on exposure to toxic substances [41]. It has the advantages of detection over several months, noninvasive sampling, easy storage and great resistance to decomposition-unlike body fluids, for example. For all of these reasons, hair analysis has also been introduced in the field of psychobiology. Recently, cortisol analysis in hair segments has been introduced in biomedical research, showing reliable performance as a biological marker reflecting long periods of exposure to stress, and thus extending the 24-h periods available so far [42]. The question of how cortisol is incorporated to hair has not been fully clarified, though several potential mechanisms have been suggested. In this respect, cortisol diffusion from follicular capillaries into the medulla of the hair shaft during growth [43] is the most widely accepted explanation, due to its low molecular weight and lipophilic nature that make it easy for the molecule to enter the cells. As a result, the cortisol deposited into growing hair reflects cortisol production under central HPA control.

Furthermore, the presence of a local HPA-like pathway in the hair follicle has been suggested, leading to cortisol production [44], based on studies in human scalp follicles cultured in vitro that have identified autonomous cortisol synthesis. Similarly, another study [45] recorded local cortisol production by hair follicles in response to cold (the cold pressor test), independently of the central HPA axis. However, the low hair cortisol concentration (HCC) levels found in patients with Addison's disease suggest that the overall contribution of this alternative source to total HCC may be small [45].

Diffusion from sebum and sweat secretions into the hair follicle after formation has also been suggested [46]. The deposition of cortisol on hair from environmental exogenous sources is also possible (normally removed in a washing step of the experimental cortisol extraction procedure), though it remains unclear whether this external cortisol is incorporated into the shaft.

In the same way as cortisol measurements in saliva, cortisol concentrations in hair reflect levels of free cortisol [47], though the measurement of cortisol in hair moreover affords a reliable long-term index (of the order of months) of the activity of the HPA axis and of the systemic response to chronic stressors. The need for retrospective information about the activity of the HPA axis over long periods of time (weeks to months), and definition of the protocol for cortisol assessment in human hair samples [48], have caused hair to become increasingly interesting as a noninvasive sample material both for clinical diagnostic and research purposes.

Several advantages encourage the use of hair samples to assess cortisol concentration: (a) hair offers retrospective information about the accumulation of cortisol, allowing the measurement of chronic stress over a long term. Cortisol production in response to a stressor could be examined later in time without needing to collect the sample in the moment when stress is actually occurring. The mean hair growth rate averages about 1 $\mathrm{cm} /$ month [49]. Accordingly, $1 \mathrm{~cm}$ of hair from the scalp may represent the cortisol accumulation of one month, $2 \mathrm{~cm}$ of hair from the scalp may represent the cortisol accumulation of two months, and so on; (b) baseline cortisol accumulation may be recorded; samples could be extracted in the period during which stress has not yet occurred; (c) sampling is noninvasive and painless; the stress of venous sample extraction therefore can be avoided; and (d) sampling is easy, with no need for high temperature or special conditions of storage, since hair samples are characterized by great stability $[41,43]$. The role of diet and nutritional status, body mass index, pollution and drugs on cortisol accumulation in hair should also need a careful analysis in order to shed new lights on possible confounding factors in its determination and data interpretation.

The present study provides an overview of the methodological aspects of hair cortisol measurement and the correlations with cortisol levels measured in other matrices. We also provided an updated summary on the studies aimed to evaluate the relationship with hair cortisol measurement in association with sleep disorders in both adults and children. All 
original articles retrieved in the PubMed/Medline electronic bibliographic database up until 30 September 2020, were analyzed. The bibliographic searches were performed with no time limitation in each database in order to retrieve all relevant references for human studies, with the following inclusion criteria applied: (1) full text in English; (2) primary articles only; and (3) identification of data regarding measurement of cortisol measurement in hair and the analysis of hair cortisol with sleep quality and/or sleep disorders. The title and abstract were analyzed to determine which articles to include. The full text was retrieved for those that fulfilled the inclusion criteria. Finally, the reference lists of all the relevant articles were manually cross-referenced to identify any additional articles. The primary search terms used were "hair", "cortisol" AND "sleep".

\section{Experimental Approaches to Cortisol Analysis}

Several experimental approaches have described the way to extract and analyze hair cortisol and its concentration. In general, the main methodological steps comprise a hair sampling process, hair cutting, or pulverization, and cortisol extraction in an organic solvent. The extraction medium is then evaporated to dryness and reconstituted in saline solution or distilled water $[4,42,50]$.

Balagova and Jezova [51] underscore that close attention must be paid to many methodological details, including the washing method, the timing and extent of sample preparation, and concrete aspects referred to the centrifugation conditions. These authors were able to optimize the cortisol extraction procedure, modifying the pulverization, methanol extraction and centrifugation steps.

The quantity of hair needed for this process is usually between 8 and $50 \mathrm{mg}[4,42,50]$, and the segment lengths depend on the period of interest to be examined. Nevertheless, cortisol analysis is generally limited to the $6 \mathrm{~cm}$ (equivalent to 6 months) near to the scalp, because some studies have found hair extremities to be more vulnerable to degradation, and the cortisol concentrations decline as the segments lie further away from the scalp [42]. Eighteen-month hair cortisol concentrations have been assessed in some studies, however $[27,28]$. It is advisable to obtain the hair sample from the posterior vertex of the head, which is considered to be the region in which hair growth is more stable and exhibits less intra-individual variation [50,52].

Solid-phase enzyme-linked immunosorbent assay (ELISA), as well as luminescence immunoassay, LIA and radioimmunoassay (RIA) and liquid chromatography-mass spectroscopy (HPLC or LC-MS/MS) have been used to measure the concentration of cortisol in hair extracts $[42,48,53-56]$. However, because of their simplicity and low cost, ELISA kits remain the most common method used [56], even if the commercially available kits are designed for cortisol measurement in saliva rather than hair extracts [56]. Slominski et al. [57] reported that ELISA-based assays afford greater sensitivity in measuring hair cortisol levels than LC-MS-based assays. Russel et al. [58] compared four immunoassay methods and two liquid chromatography-mass spectrometry (LC-MS/MS) techniques used by four leading laboratories in hair cortisol testing, and found the results to be strongly and positively inter-correlated when analyzing a common batch of hair. Thus, laboratories using immunoassays can use a correction factor to convert the results into standard LC-MS/MS equivalents.

Careful interpretation is required when measuring hair cortisol concentration, because several confounding factors may intervene, such as radiation exposure [59], extensive washing and brushing [52,60], and chemical treatments, such as shampoos and dyes [61,62]. However, natural hair color does not seem to influence hair cortisol concentration [48,52]. Furthermore, subject age and sex [25,63], physical exercise [64], and the presence of certain comorbidities, such as diabetes and cardiovascular disorders [65] should be taken into account when measuring hair cortisol [64]. 


\section{Correlation between Cortisol in Hair and in Body Fluids Used in Biomarker Analysis}

To confirm the validity of scalp hair cortisol as a biological marker of retrospective systemic levels of cortisol, analyses have been made of the correlations of hair cortisol concentration (HCC) with cortisol extracted from other biological samples. It was predictable and not surprising that cortisol in hair does not correlate strongly with cortisol in other body matrices, since the latter are mainly collected only once or a few times to measure short-term cortisol exposure, while hair reflects long-term exposure. On the other hand, samples collection over a relatively long period of time may mask daily cortisol fluctuations and, thus, presumably afford a better correlation. No statistically significant correlations have been found between HCC and cortisol in one-time (point) samples of morning blood serum [52] and blood serum collected after an overnight fast [66]. In comparison, weak to moderate correlations were found with urinary cortisol.

Sauvé et al. [52] found a low yet significant correlation between hair cortisol levels and cortisol in 24-h urine, but not with serum or salivary cortisol obtained at a single time point. However, van Ockenburg et al. [67] reported a moderate and nonsignificant correlation between hair cortisol concentration and 24-h urinary cortisol concentration, even when collected over a period of 63 days. In turn, Short et al. [68] observed no correlation between cumulative one-month cortisol production in hair and the average of four weekly $24-\mathrm{h}$ urinary free cortisol (UFC) determinations. Cortisol conversion or degradation could explain the lack of an association to cortisol levels in urine.

Regarding correlations with saliva, HCC was found to be moderately correlated with the mean salivary cortisol concentrations taken on three days (samples were collected at 6 timepoints on each day) [69]. Xie et al. [70] found a significant correlation between HCC in 1-cm hair segments and average salivary cortisol corresponding to three samplings (at 1, 2, and 3 weeks). The relevant study by D'Anna-Hernandez and collaborators [71] showed that cortisol concentration in hair and saliva increases throughout pregnancy, and decreases in the postpartum period. Thus, hair samples collected during pregnancy allow access to HPA activity in the first trimester, a time that was previously difficult to obtain because women may not realize they are pregnant or delay medical care until the end of the first or beginning of the second trimester, when they could be recruited for a study. Prenatal cortisol levels in the hair showed a previously verified pattern unique to pregnancy that suggests that cortisol in the hair is a convincing reflection of cortisol release over a three-month period. The high cortisol levels in the third trimester were replicated in hair, serum and saliva. The correlation of cortisol levels in hair and saliva suggests that hair cortisol levels are a useful marker of overall maternal HPA activity during each trimester. Vanaelst et al. [72] also found HCC to be significantly correlated with the salivary cortisol output (area under the curve (AUC)) of salivary cortisol collected over two consecutive days (samples were taken at four timepoints on each day). The HCC of daughters was found to be positively related to their AUC following social stress in a study of HCC as a marker of psychosocial stress in mother-daughter dyads [73]. Similarly, Kao et al. [74], in children, recorded a correlation between HCC and the AUC of salivary cortisol production in response to stress. Short et al. [68] examined the correlation between HCC and cortisol from saliva collected over the same period of one month. They found HCC to be most strongly associated with the salivary cortisol AUC over the whole month. These authors observed that the magnitude of the correlations of HCC with salivary cortisol AUC increased steadily with progressing time. Using weekly average AUC scores, summed to reflect the accumulation of time, the magnitude of the associations increased from the prior week to the prior two weeks, the prior three weeks, and the prior four weeks to the whole 30-days period. They also confirmed that HCC reflects cumulative cortisol production over a period rather than the diurnal rhythmicity of cortisol secretion.

Few studies $[63,69,75]$ have used fingernails as a matrix to measure cortisol, due to inter-individual variability of the growth rate, and the difficulty of obtaining a sufficient sample. Izawa et al. [75] found the cortisol level in saliva over the whole day (AUC for 
cortisol) to be moderately associated with the cortisol level measured in fingernail samples that were collected four months and 5 months later.

\section{Cortisol and Sleep}

Sleep is a basic human need and a pillar of health [76], and is very necessary for the neurological development of infants and children. In addition, it is essential for good quality of life, better productivity, and general well-being [77].

Insufficient sleep or sleep disturbances have adverse effects upon health $[78,79]$ and have been associated with poor physical, mental and cognitive functioning [80,81], including insulin resistance, obesity, arterial hypertension, poor cardiovascular health [79,82-85], depression, suicidal behavior, and other self-injurious behaviors [84,86-88], as well as overall mortality $[89,90]$. Sleep disruption is associated with poor mental health [91], both as a cause [92-95] and consequence [96-99].

Growing evidence suggests stress and its related physiological changes to constitute a possible link between poor sleep and adverse health effects. In particular, results from animal and human studies indicate bidirectional effects between sleep and the HPA axis $[100,101]$.

Several studies have revealed that poor sleep is directly associated with increased basal activity of the HPA axis, and it has further been suggested that poor sleep may potentiate the responsiveness of this system to menace and defiance $[100,102,103]$. This possibility has been supported by a study [104] reporting strong relationships between poor sleep quality and subsequent dysregulation of the cortisol response to various stressors. Especially, poor sleep quality has been shown to predict exaggerated cortisol responses to both physiological [105] and psychological stressors [106]. It is worthy to note that repeated or chronic activation of the HPA axis may cause dysfunctions of the latter [107]. These dysfunctions may be preceded by changes in acute HPA reactivity patterns, which could be useful as early warning signs of elevated health risks. Indeed, HPA axis dysfunctions have consistently been shown to have an impact upon physiological and mental health [108], thus presenting a pathway contributing to the effects of poor sleep upon health [109].

Cortisol being the end product of the HPA axis may reflect activation of the neuroendocrine system; for this reason, it is largely used as a marker of neuroendocrine response to stress both in children and in adults $[110,111]$.

Cortisol concentrations have been measured in several biological matrices such as saliva, urine, blood and, more recently, hair. The use of this latter matrix is an emerging method for measuring early childhood (12-60 months of age) persistent stress, and is a promising strategy for assessing chronic physiological stress responses in adults [52,112]. Hair cortisol concentration is increasingly used as a marker of HPA axis activity particularly in psycho-neuroendocrine research [113].

\subsection{Hair Cortisol and Sleep in Adults}

As already mentioned, sleep displays a close and reciprocal relationship with the functioning of the HPA axis $[101,103,104,114]$. Several lines of evidences have shown that stress-inducing factors can have a significant impact upon the sleep-wake cycle in various ways, depending mainly on the type of stressors and the duration of exposure (acute or chronic), as well as on inter-individual differences [115-118]. Increased stress reactivity of the HPA axis to physical and psychosocial stressors has been evidenced in people with poor quality sleep [119]. Chronic stressors profoundly impact upon human sleep architecture, as have been reported in cases of marital separation [120], burnout patients [121], or shift work [118]. In addition, higher levels of sleepiness, more frequent awakenings, lesser sleep efficiency and disturbed sleep quality have been reported in individuals with high burnout [122,123]. The characteristic of the studies evaluating hair cortisol concentration in adults and its relationship with sleep quality are shown in Table 1. 
Table 1. Hair cortisol and sleep disorders in adults.

\begin{tabular}{|c|c|c|c|c|c|}
\hline Reference & Number of Adults and Mean Age & Characteristics of Participants & $\begin{array}{c}\text { How the Analysis of Sleep was } \\
\text { Performed }\end{array}$ & $\begin{array}{l}\text { Mean Concentration of Hair } \\
\text { Cortisol (HCC) }\end{array}$ & $\begin{array}{l}\text { Main Findings of the Study Related } \\
\text { to Hair Cortisol Concentration }\end{array}$ \\
\hline Lanfear et al., 2020 & $\begin{array}{ll}- & \mathrm{N}=42 \\
\quad & \text { Age: } 60-80 \text { years } \\
& \text { Mean age: } 68.1 \pm 5.3 \text { years. }\end{array}$ & $\begin{array}{l}\text { Male and female over the age } \\
\text { of } 60 \text { years; older adults in } \\
\text { good general physical health. } \\
\text { Participants were divided into } \\
\text { two categories based on } \\
\text { whether they did or did not } \\
\text { sleep during the day. }\end{array}$ & $\begin{array}{l}\text { An ad hoc questionnaire to capture } \\
\text { physiological data: time and duration } \\
\text { of daytime sleep. }\end{array}$ & $\begin{array}{ll}\text { - } & \text { HCC levels: } 1.4-82.5 \mathrm{pg} / \mathrm{mg} \\
\text { - } & \text { Median HCC: } 5.65 \mathrm{pg} / \mathrm{mg} \\
& \text { Mean HCC: } \\
& 10.5 \mathrm{pg} / \mathrm{mg} \pm 13.6 \mathrm{pg} / \mathrm{mg} \\
& \text { Mean HCC in males }(\mathrm{n}=20) \\
& \text { was } 14.4 \mathrm{pg} / \mathrm{mg} \\
& \text { Mean HCC in females }(\mathrm{n}=22) \\
& \text { was } 6.8 \mathrm{pg} / \mathrm{mg}\end{array}$ & $\begin{array}{l}\text { HCC in older adults trends to } \\
\text { be higher in comparison with } \\
\text { toddlers and adolescents. } \\
\text { A significant difference in hair } \\
\text { cortisol between males and } \\
\text { females older adults. } \\
\text { No significant difference in } \\
\text { hair cortisol between } \\
\text { participants who did and did } \\
\text { not sleep during the day. }\end{array}$ \\
\hline Trikojat et al, 2017 & $\begin{array}{ll}- & \text { Season Allergic Rhinitis (SAR) } \\
& \text { patients }(\mathrm{n}=41) \\
\text { - } & \text { Age mean: } 24.12( \pm 3.3) \text { years } \\
\text { - } & \text { Healthy controls }(\mathrm{n}=42) \\
& \text { Age mean: } 24.43( \pm 3.1) \text { years. }\end{array}$ & $\begin{array}{l}\text { SAR patients reported rhinitis } \\
\text { symptoms exclusively during } \\
\text { pollen season and had a } \\
\text { positive skin prick test for at } \\
\text { least one grass or tree pollen } \\
\text { and/or elevated total IgE level } \\
\text { (>100 IU/mL serum). } \\
\text { All patients were off allergy } \\
\text { medication for at least seven } \\
\text { days prior to testing. }\end{array}$ & $\begin{array}{l}\text { Pittsburgh Sleep } \\
\text { Quality Index (PSQI; Buysse et al., } \\
\text { 1989). }\end{array}$ & $\begin{array}{ll}- & \text { Hair Cortisol, pg/mg } \\
\text { - } & \text { SAR patients: On-pollen } \\
& \text { season } 5.4( \pm 4.3) \text { Off-pollen } \\
\text { season } 4.2( \pm 2.5) & \\
\text { Healthy controls: On-pollen } \\
\text { season } 5.9( \pm 4.2) \text { Off-pollen } \\
\text { season } 4.1( \pm 2.6)\end{array}$ & $\begin{array}{ll}\text { - } & \text { No significant group } \\
\text { differences in HCC could be } \\
\text { found in both testing seasons. } \\
\text { On allergy season, Beck } \\
\text { Depression Inventory II sum } \\
\text { score correlates with PSQI but } \\
\text { not with HCC in SAR patients. }\end{array}$ \\
\hline
\end{tabular}


Table 1. Cont.

\begin{tabular}{|c|c|c|c|c|c|}
\hline Reference & Number of Adults and Mean Age & Characteristics of Participants & $\begin{array}{l}\text { How the Analysis of Sleep was } \\
\text { Performed }\end{array}$ & $\begin{array}{l}\text { Mean Concentration of Hair } \\
\text { Cortisol (HCC) }\end{array}$ & $\begin{array}{l}\text { Main Findings of the Study Related } \\
\text { to Hair Cortisol Concentration }\end{array}$ \\
\hline Wang et al., 2019 & 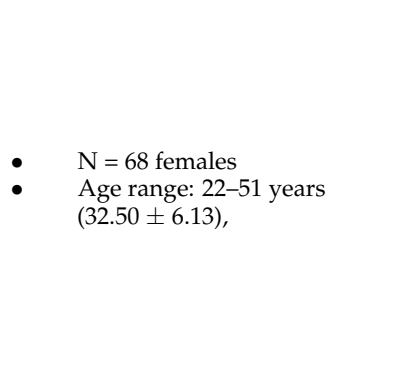 & $\begin{array}{l}\text { Participants were employees } \\
\text { working in both clinical and } \\
\text { management roles, who had } \\
\text { worked continuously in the } \\
\text { same position for at least } 6 \\
\text { months, and } \\
\text { Participants had no history of } \\
\text { mental illness and no history of } \\
\text { psychotropic drug use for } 1 \\
\text { week prior to the investigation, } \\
\text { basing on the clinical records } \\
\text { and self-report of each } \\
\text { participant. }\end{array}$ & Athens Insomnia Scale (AIS), & $\begin{array}{l}\text { - } \quad \text { HCC median: } 5.89 \mathrm{ng} / \mathrm{g} \text { hair } \\
\text { Interquartile HCC range: } \\
\text { 2.20-10.74 ng/g hair }\end{array}$ & $\begin{array}{ll}\text { - } & \text { HCC was significantly } \\
\text { associated with insomnia. } \\
\text { - } \\
\text { of significant mediating effect } \\
\text { of HCC on the path from } \\
\text { insomnia to burnout. } \\
\text { Both burnout and insomnia } \\
\text { were associated with elevated } \\
\text { HCC among female employees } \\
\text { of hospital. }\end{array}$ \\
\hline Colledge et al., 2017 & $\begin{array}{l}\text { Patients with aneurysmal } \\
\text { subarachnoid hemorrhage (aSAH) } \\
\text { - } \quad \mathrm{N}=32: 22 \text { women, } 10 \text { men; } \\
\text { Mean age: } 57.4 \pm 10.7 \text { years; } \\
\text { Healthy controls } \\
\text { - } \quad \mathrm{N}=17: 11 \text { women, } 6 \text { men; } \\
\quad \quad \text { Mean age }=59.8 \pm 10.8 \text { years }\end{array}$ & $\begin{array}{l}\text { Patients with aSAH following } \\
\text { neurosurgical or endovascular } \\
\text { intervention. }\end{array}$ & $\begin{array}{l}\text { The 7-item Insomnia Severity Index } \\
\text { (Bastien CH, Vallieres A, Morin CM, } \\
\text { 2001) }\end{array}$ & 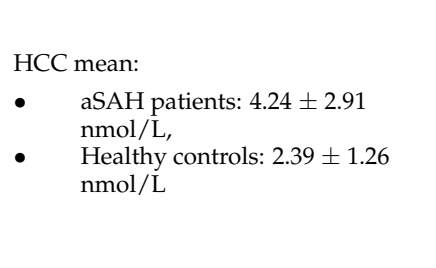 & $\begin{array}{l}\text { - HCCs were significantly higher } \\
\text { in aSAH patients compared to } \\
\text { healthy controls. } \\
\text { In aSAH patients, higher HCCs } \\
\text { were significantly associated } \\
\text { with increased sleep } \\
\text { complaints. } \\
\text { aSAH patients exhibited more } \\
\text { sleep complaints. }\end{array}$ \\
\hline Feller et al., 2014 & $\begin{array}{ll}- & \mathrm{N}=680 \text { participants }(369 \\
& \text { women) } \\
\text { - } & \text { Mean age: } 65.8 \text { years } \\
\text { Range age: } 47-82 \text { years. }\end{array}$ & $\begin{array}{l}\text { Participants in middle and old } \\
\text { adulthood not using } \\
\text { glucocorticoid-containing treatments. }\end{array}$ & $\begin{array}{l}\text { Average night and daytime sleep was } \\
\text { collected using questionnaires }\end{array}$ & $\begin{array}{l}\text { Mean } \pm \text { SD HCC in the whole } \\
\text { sample were } \\
35.1 \pm 32.8 \mathrm{pg} / \mathrm{mg} \text {. } \\
\text { Mean } \pm \text { SD SCC were } \\
37.9 \pm 34.0 \mathrm{pg} / \mathrm{mg} \text { in men and } \\
32.7 \pm 31.6 \mathrm{pg} / \mathrm{mg} \text { in women. } \\
\text { HCC outlying by } 3 \text { standard } \\
\text { deviations (SD) from the mean } \\
\text { were excluded ( }=18 \text { ) after the } \\
\text { initial elimination of extreme } \\
\text { values }>500 \mathrm{pg} / \mathrm{mg}(\mathrm{n}=8), \\
\text { resulting in a final sample of } \\
\text { 654 participants for further } \\
\text { analyses. }\end{array}$ & $\begin{array}{l}\text { - A linear increase in HCC with } \\
\text { participant ages was found and } \\
\text { this relationship was } \\
\text { maintained regardless of the } \\
\text { influence of other age-related } \\
\text { variables (body mass, physical } \\
\text { activity, alcohol consumption, } \\
\text { smoking). } \\
\text { HCC was found to be } \\
\text { positively related daytime } \\
\text { sleeping. } \\
\text { In multiple regression analysis, } \\
\text { daytime sleeping was not a } \\
\text { predictor factor of HCC. }\end{array}$ \\
\hline
\end{tabular}


Wang et al. [124] examined the role of HPA axis activity in female employees of hospitals, and found both burnout and insomnia to be associated with elevated HCC. Likewise, burnout and insomnia have been shown to be significantly and bi-directionally associated, and mutually influence each other.

In general, strong activation of the HPA axis can lead to shortened sleep time, decreased slow-wave sleep (SWS) and sleep fragmentation [100], while insufficient sleep promotes basal activity of the HPA axis $[103,104]$. Animal studies have further revealed that chronic sleep disorders can induce fundamental neuroendocrine changes that may eventually influence HPA stress reactivity [103].

The quality of sleep is found to particularly influence cortisol stress responsiveness. This relates to both subjectively reported sleep quality and objectively measured sleep efficiency, awakenings during the night and time spent in lighter sleep phases. In contrast, normal variations in sleep duration do not seem to influence HPA reactivity, whereas daytime sleepiness is associated with blunted cortisol stress responsiveness [119].

The relationship between sleep and HPA axis activity has most often been assessed based on the cortisol awakening response (CAR) or the rise in cortisol measured approximately $30 \mathrm{~min}$ after awakening [125]. An increase in CAR has also been shown to follow poor sleep [126], though not all studies report this association [125]. A study involving postmenopausal women reported different associations between sleep quality indices and altered diurnal cortisol rhythms [127]. It has also been reported that in normal subjects, plasma cortisol levels correlate positively with induced sleep disruption [128] and negatively with total sleep time [129].

By measuring the correlation between the concentration of cortisol in saliva and sleep disturbances, participants who had a decrease of $50 \%$ or more in sleep duration showed a more marked increase in CAR compared to those who never reported sleep problems [130].

Another study in Korean firefighters using serum cortisol indicated that the serum cortisol response was positively related to nightshift work, and the serum cortisol levels differed according to the shift schedule involved [131]. Janssens et al. [132] showed that employees working a fixed day shift have significantly higher HCC levels than those involved in variable shift work.

The relationship between hair cortisol and sleep disorders has not been investigated in depth. A recent study has suggested HCC as a biomarker for sleep disorders caused by shift work [133]. The authors reported that workers with high HCC had a higher prevalence of sleep disorders compared with workers with low and intermediate HCC levels [133]. Similarly, in aneurysmal subarachnoid hemorrhage (aSAH) patients, higher HCC levels were significantly associated with increased sleep complaints [134].

In turn, a study by Feller et al. [135] suggested that daytime sleeping is positively related to higher hair cortisol levels in older individuals. In contrast, a recent study published by Lanfear and Voegel et al. [136] in older adults recorded no association between daytime sleeping and hair cortisol.

These controversial results could be due to the differences in sleep duration. Since endogenous cortisol levels increase shortly after waking, it would be expected that the HCC levels would be higher in adults who are sleeping during the day for a long period, and not in individuals who sleep for only a very short time [137].

\subsection{Hair Cortisol and Sleep in Children}

The activity of the HPA axis is typically assessed by measuring cortisol as the end product of the axis [138]. The variation in diurnal cortisol secretion patterns has been linked to sleep behavior [106,137-139]. These associations may be especially important for understanding the mechanisms underlying these bidirectional associations during the pre- and post-adolescent years when these subjects are experiencing significant physical, neurobiological, and socioemotional changes [140,141].

It has been reported that chronic sleep difficulties and insufficient sleep experienced during childhood independently result in the development of later physical and mental 
health problems in many young individuals [142,143]. Several epidemiological studies have reported that up to $50 \%$ of all children experience sleep problems [144-146], often having poor sleep health, including insufficient sleep duration and/or poor sleep efficiency $[147,148]$. Additionally, insufficient sleep has been related to multiple problems, such as an increase in risk-taking behaviors [149] and a decline in school performance [150].

The relationships between sleep and the HPA axis have not been widely investigated in children. The few studies that have examined sleep and basal salivary cortisol in infancy support the sensitivity of the infant HPA axis to sleep [151,152]. Indeed, in infants, higher waking salivary cortisol concentration (SCC) and the cortisol awakening response (CAR) were associated with taking more daytime naps, and were positively related to later sleep onset [151]. Likewise, in infants between 2 and 4 years of age, lower waking SCC the next morning was associated with forced sleep restriction, and CAR was associated with day-time naps [152].

Other studies have reported that children with short and poor sleep present increased HPA axis activity after awakening [106,153,154]. Increased morning cortisol secretion in children with short sleep duration, shorter relative amounts of slow-wave sleep (SWS), longer relative amounts of light sleep (including stage 1 sleep and stage 2 sleep), and rapid-eye-movement (REM) sleep have been reported [155,156].

Importantly, there is evidence that sleep quality (nocturnal awakening, disordered breathing, SWS) is affected in children born very preterm in comparison with term born peers $[157,158]$, which may lead to sleep disturbances during adolescence and young adulthood, with earlier bedtimes and circadian preferences [159-161]. Recent studies have examined the relationship between hair cortisol and sleep in children (Table 2).

Although little is known about the potential long-term health effects of elevated hair cortisol in children, a study conducted in children born into families affected by multiple adverse psychosocial exposures found that such children seemed to have higher cortisol levels and were significantly more affected by the most common childhood disease conditions [162]. In the same sense, Vanaelst and al. [66] reported a positive correlation between HCC and major childhood life events in children.

A study assessing the relationship between hair cortisol and sleep duration in 12-month old infants reported that HCC in infants who slept $10 \mathrm{~h}$ or more each night were lower than in infants who slept less than $10 \mathrm{~h}$ [163]. However, a recent study examining the association between sleep quality and quantity and chronic stress levels of hair cortisol in children aged 2-6 years reported no association between sleep and cortisol levels [164].

Nevertheless, authors that have examined the association between sleep quality and salivary cortisol levels among children seem to generally agree that shorter sleep duration and/or longer sleep onset latency is directly related to cortisol measured in saliva, in both longitudinal and cross-sectional studies. Findings from several studies in children have reported direct associations between salivary cortisol levels and poor sleep habits, sleep patterns, and sleep problems, including shorter sleep duration and poorer sleep quality $[155,156,165,166]$.

Childhood HPA function is complex, and various measures of cortisol in children are essential to allow comprehensive understanding of its environmental correlates and long-term implications. In this regard, research into the association between hair cortisol and sleep is still in its beginnings, and future long-term studies affording more detailed information on objectively measured sleep are still needed to determine whether high hair cortisol may influence sleep characteristics in children. 
Table 2. Hair cortisol and sleep disorders in children.

\begin{tabular}{|c|c|c|c|c|c|}
\hline Reference & $\begin{array}{c}\text { Number of Children and } \\
\text { Mean Age }\end{array}$ & $\begin{array}{l}\text { Characteristics of } \\
\text { Participants }\end{array}$ & $\begin{array}{c}\text { How the Analysis of Sleep } \\
\text { Was } \\
\text { Performed }\end{array}$ & $\begin{array}{c}\text { Mean Concentration of Hair } \\
\text { Cortisol (HCC) }\end{array}$ & $\begin{array}{l}\text { Main Findings of the Study } \\
\text { Related to Hair Cortisol } \\
\text { Concentration }\end{array}$ \\
\hline Flom et al., 2017 & $\begin{array}{ll}\text { - } & \text { Age: } 12 \text { months. } \\
\text { - } & \text { Mean age: } 12.18 \\
\text { - } & \mathrm{N}=111\end{array}$ & $\begin{array}{l}\text { Healthy infants who } \\
\text { had no known hearing, } \\
\text { visual, neurological, or } \\
\text { developmental } \\
\text { disorders. } \\
\text { Infant ethnicity: } \\
\text { Caucasian } 65.5 \% \text { Asian } \\
4.5 \% \text { Black } 4.5 \% \\
\text { Hispanic } 1.8 \% \text { Native } \\
\text { American } 0 \% \\
\text { Multiracial/Other } 23.6 \% \\
\text { Infants were classified } \\
\text { into High HCC and Low } \\
\text { HCC } \\
\text { Salivary Cortisol } \\
\text { concentrations (SCC) } \\
\text { were also measured at } \\
\text { waking and bedtime } \\
\text { and infants were } \\
\text { classified to steep slope } \\
\text { and flat slope. }\end{array}$ & $\begin{array}{l}\text { The Brief Infant Sleep } \\
\text { Questionnaire (BISQ; } \\
\text { Sadeh, 2004) completed } \\
\text { by mothers. } \\
\text { Infant nighttime sleep } \\
\text { duration: time in hours } \\
\text { that the infant typically } \\
\text { spends asleep between } 7 \\
\text { p.m. and } 7 \text { a.m. } \\
\text { Sleep disruption: } \\
\text { number of night } \\
\text { wakings (<2 times; }>2 \\
\text { times per night). }\end{array}$ & $\begin{array}{l}\text { - } \quad \mathrm{HCC}(\mathrm{pg} / \mathrm{mg}): \\
86.26 \pm 183.63\end{array}$ & $\begin{array}{l}\text { - Infants who slept } 10 \mathrm{~h} \text { or } \\
\text { more each night at } 12 \\
\text { months had lower HCC } \\
\text { than infants who slept } \\
\text { less than } 10 \mathrm{~h} \text {. } \\
\text { - } \\
\text { hleep disruption was } \\
\text { higher for infants with } \\
\text { flat slope/high HCC } \\
\text { compared to infants } \\
\text { with a steep slope/high } \\
\text { HCC. } \\
\text { Higher infant HCC was } \\
\text { associated with greater } \\
\text { infant waking SCC, } \\
\text { bedtime SCC, but not } \\
\text { with diurnal slope. } \\
\text { Sleep disruption was } \\
\text { not related to infant } \\
\text { HCC at } 12 \text { months. }\end{array}$ \\
\hline Eythorsdottir et al., 2020 & $\begin{array}{ll}\text { - } & \text { Age: } 2-6 \text { years. } \\
\text { - } & \text { Mean age: } 5.3 \text { years. } \\
& \mathrm{N}=68 \text { for sleep } \\
\text { information. } \\
\text { - } \\
\quad \mathrm{N}=72 \text { for hair cortisol } \\
\text { measurements. }\end{array}$ & $\begin{array}{l}\text { Pre-school children having } \\
\text { factors for overweight } \\
\text { predisposition. }\end{array}$ & $\begin{array}{l}\text { Objective sleep characteristics } \\
\text { (sleep duration, sleep latency } \\
\text { and sleep efficiency) assessed } \\
\text { by an ActiGraph GT3X } \\
\text { during a continuous period } \\
\text { of } 5 \text { days and nights. }\end{array}$ & $\begin{array}{l}\text { - } \quad \text { Cortisol levels }(\mathrm{pg} / \mathrm{mg}) \text { : } \\
109 . \\
\text { - } \quad \text { Cortisol levels overall } \\
\text { median range }=7-890 .\end{array}$ & $\begin{array}{l}\text { Sleep characteristics were } \\
\text { generally not associated with } \\
\text { log transformed cortisol } \\
\text { levels. }\end{array}$ \\
\hline
\end{tabular}


Table 2. Cont.

\begin{tabular}{|c|c|c|c|c|c|}
\hline Reference & $\begin{array}{c}\text { Number of Children and } \\
\text { Mean Age }\end{array}$ & $\begin{array}{l}\text { Characteristics of } \\
\text { Participants }\end{array}$ & $\begin{array}{c}\text { How the Analysis of Sleep } \\
\text { Was } \\
\text { Performed }\end{array}$ & $\begin{array}{l}\text { Mean Concentration of Hair } \\
\text { Cortisol (HCC) }\end{array}$ & $\begin{array}{l}\text { Main Findings of the Study } \\
\text { Related to Hair Cortisol } \\
\text { Concentration }\end{array}$ \\
\hline Maurer et al., 2016 & $\begin{array}{l}\text { Healthy children born very } \\
\text { preterm (<32nd gestational } \\
\text { weeks): } \\
\text { - } \quad \text { Mean age: } 9.5 \pm 1.4 \\
\text { years. } \\
\text { - } \quad \text { Age range: } 7.4-12.4 \\
\text { - } \quad \mathrm{N}=85 \\
\text { Healthy children full term } \\
\text { born: } \\
\text { - } \quad \text { Mean age: } 9.6 \pm 1.4 \\
\text { - } \quad \text { Age range: } 6.9-13 \\
\text { - } \quad \mathrm{N}=91\end{array}$ & $\begin{array}{l}\text { Healthy children at school } \\
\text { age. }\end{array}$ & $\begin{array}{l}\text { - } \quad \text { Sleep was assessed } \\
\text { using in-home } \\
\text { polysomnography (PSG) } \\
\text { during a single night at } \\
\text { the children's home. } \\
\text { Objective sleep indices } \\
\text { were evaluated: sleep } \\
\text { continuity, sleep } \\
\text { efficiency and nocturnal } \\
\text { awakening. } \\
\text { Sleep architecture (\%): } \\
\text { Stage } 1 \text { sleep, stage } 2 \\
\text { sleep, SWS (SWS: Stages } \\
3 \text { and } 4 \text { sleep), REM } \\
\text { sleep, and REM latency } \\
\text { (min). }\end{array}$ & $\begin{array}{l}\text { - Hair cortisol values } \\
\text { (truncated to a value of } \\
2 \text { inter quartile above } \\
\text { the median and } \\
\text { adjusted for } \\
\text { socio-demographic } \\
\text { characteristics) } \\
\text { - } \quad \text { Very pre-term } \\
\text { - Cortisol mean: } 2.0 \pm 2.1 \\
\text { Full-term } \\
\text { - Cortisol mean: } 1.9 \pm 1.8\end{array}$ & $\begin{array}{l}\text { - A negative association } \\
\text { between hair cortisone } \\
\text { and child age; boys had } \\
\text { significantly higher hair } \\
\text { cortisol and cortisone } \\
\text { levels than girls. } \\
\text { A negative association } \\
\text { between sleep duration } \\
\text { and child age; boys } \\
\text { showed longer REM } \\
\text { sleep latency than girls. } \\
\text { No other significant } \\
\text { relations between sleep } \\
\text { measures and child age. }\end{array}$ \\
\hline
\end{tabular}


In sum, sleep plays an important role in maintaining adequate neuroendocrine stress reactivity, and inadequate sleep potentiates the stress reactivity of the HPA axis [119]. Evidence from experimental studies has established that sleep affects HPA function [109,167,168]. Accordingly, impaired sleep increases the activity of the HPA axis [103,104], and elevated levels of HPA hormones are found to result in inadequate sleep [169-171]. Although the relationship between sleep and the HPA axis is clearly bidirectional, these findings support the assumption that sleep specifically modulates the stress sensitivity of the HPA axis.

\section{Conclusions}

Cortisol alterations seem to be intimately associated with sleep disorder and the development of neuropsychiatric disorders and symptoms. Sleep disorders associated with high cortisol levels in both adults and children. However, we need studies to assess whether hair cortisol can also reflect the effects of pharmacological and non-pharmacological interventions aimed to improve sleep quality. The measurement of hair cortisol and its relationship with more "acute" measurements, e.g., saliva and blood levels is particularly warranted in patients with severe cognitive impairment in which clinical assessment of sleep complaints is difficult or impossible. The role of diet and nutritional status, body mass index, pollution, and drugs on cortisol accumulation in hair should also need a careful analysis in order to shed new lights on possible confounding factors in its determination and data interpretation. Many studies indicate that hair cortisol constitutes a valuable tool to further supplement existing data on salivary, plasma, or urinary cortisol concentrations in patients with sleep disorders, and future studies would validate hair cortisol determinations as diagnostic and prognostic tool in several neuropsychiatric and endocrine disorders.

Author Contributions: Conceptualization, N.E.M., H.A. and O.C.; methodology, N.E.M., H.A. and O.C.; writing-original draft preparation, N.E.M., H.A.; writing—review and editing O.C.; and supervision, O.C. All authors have read and agreed to the published version of the manuscript.

Funding: This research received no external funding.

Conflicts of Interest: The authors declare no conflict of interest.

\section{References}

1. O'Connor, T.M.; O'Halloran, D.J.; Shanahan, F. The Stress Response and the Hypothalamic-Pituitary-Adrenal Axis: From Molecule to Melancholia. QJM Mon. J. Assoc. Physicians 2000, 93, 323-333. [CrossRef] [PubMed]

2. Aminkeng, F.; Ross, C.J.D.; Rassekh, S.R.; Hwang, S.; Rieder, M.J.; Bhavsar, A.P.; Smith, A.; Sanatani, S.; Gelmon, K.A.; Bernstein, D.; et al. Recommendations for Genetic Testing to Reduce the Incidence of Anthracycline-Induced Cardiotoxicity. Br. J. Clin. Pharmacol. 2016, 683-695. [CrossRef] [PubMed]

3. Smith, L.K.; Cidlowski, J.A. Glucocorticoid-Induced Apoptosis of Healthy and Malignant Lymphocytes. Prog. Brain Res. 2010, 182, 1-30. [CrossRef] [PubMed]

4. Davenport, M.D.; Lutz, C.K.; Tiefenbacher, S.; Novak, M.A.; Meyer, J.S. A Rhesus Monkey Model of Self-Injury: Effects of Relocation Stress on Behavior and Neuroendocrine Function. Biol. Psychiatry 2008, 63, 990-996. [CrossRef]

5. Burke, H.M.; Davis, M.C.; Otte, C.; Mohr, D.C. Depression and Cortisol Responses to Psychological Stress: A Meta-Analysis. Psychoneuroendocrinology 2005, 30, 846-856. [CrossRef]

6. Handwerger, K. Differential Patterns of HPA Activity and Reactivity in Adult Posttraumatic Stress Disorder and Major Depressive Disorder. Harv. Rev. Psychiatry 2009, 17, 184-205. [CrossRef]

7. Cohen, S.I. Cushing's Syndrome: A Psychiatric Study of 29 Patients. Br. J. Psychiatry 1980, 136, 120-124. [CrossRef]

8. Loosen, P.T.; Chambliss, B.; Debold, C.R.; Shelton, R.; Orth, D.N. Psychiatrie Phenomenology in Cushing's Disease. Pharmacopsychiatry 1992, 25, 192-198. [CrossRef]

9. Dorn, L.D.; Burgess, E.S.; Dubbert, B.; Simpson, S.E.; Friedman, T.; Kling, M.; Gold, P.W.; Chrousos, G.P. Psychopathology in Patients with Endogenous Cushing's Syndrome: "Atypical" or Melancholic Features. Clin. Endocrinol. (Oxf.) 1995, 43, 433-442. [CrossRef]

10. Dimopoulou, C.; Ising, M.; Pfister, H.; Schopohl, J.; Stalla, G.K.; Sievers, C. Increased Prevalence of Anxiety-Associated Personality Traits in Patients with Cushing's Disease: A Cross-Sectional Study. Neuroendocrinology 2013, 97, 139-145. [CrossRef]

11. Dorn, L.D.; Burgess, E.S.; Friedman, T.C.; Dubbert, B.; Gold, P.W.; Chrousos, G.P. The Longitudinal Course of Psychopathology in Cushing's Syndrome after Correction of Hypercortisolism. J. Clin. Endocrinol. Metab. 1997, 82, 912-919. [CrossRef] [PubMed]

12. Miller, G.E.; Chen, E.; Zhou, E.S. If it Goes up, Must It Come down? Chronic Stress and the Hypothalamic-Pituitary-Adrenocortical Axis in Humans. Psychol. Bull. 2007, 133, 25-45. [CrossRef] [PubMed] 
13. Yehuda, R. Post-Traumatic Stress Disorder. N. Engl. J. Med. Rev. 2002, 346, 108-114. [CrossRef] [PubMed]

14. Steudte, S.; Kolassa, I.T.; Stalder, T.; Pfeiffer, A.; Kirschbaum, C.; Elbert, T. Increased Cortisol Concentrations in Hair of Severely Traumatized Ugandan Individuals with PTSD. Psychoneuroendocrinology 2011, 36, 1193-1200. [CrossRef]

15. Holtzman, C.W.; Trotman, H.D.; Goulding, S.M.; Ryan, A.T.; MacDonald, A.N.; Shapiro, D.I.; Brasfield, J.L.; Walker, E.F. Stress and Neurodevelopmental Processes in the Emergence of Psychosis. Neuroscience 2013, 249, 172-191. [CrossRef]

16. Fiksdal, A.; Hanlin, L.; Kuras, Y.; Gianferante, D.; Chen, X.; Thoma, M.V.; Rohleder, N. Associations between symptoms of depression and anxiety and cortisol responses to and recovery from acute stress. Psychoneuroendocrinology 2019, 102, 44-52. [CrossRef]

17. Jia, Y.; Liu, L.; Sheng, C.; Cheng, Z.; Cui, L.; Li, M.; Zhao, Y.; Shi, T.; Yau, T.O.; Li, F.; et al. Increased Serum Levels of Cortisol and Inflammatory Cytokines in People with Depression. J. Nerv. Ment. Dis. 2019, 207, 271-276. [CrossRef]

18. Ancelin, M.L.; Scali, J.; Norton, J.; Ritchie, K.; Dupuy, A.M.; Chaudieu, I.; Ryan, J. Heterogeneity in HPA axis dysregulation and serotonergic vulnerability to depression. Psychoneuroendocrinology 2017, 77, 90-94. [CrossRef]

19. Wichmann, S.; Kirschbaum, C.; Böhme, C.; Petrowski, K. Cortisol stress response in post-traumatic stress disorder, panic disorder and major depressive disorder patients. Psychoneuroendocrinology 2017, 83, 135-141. [CrossRef]

20. Sagarwala, R.; Malmstrom, T.; Nasrallah, H.A. Effects of nonpharmacological therapies on anxiety and cortisol: A meta-analysis. Ann. Clin. Psychiatry 2018, 30, 91-96.

21. Schmidt, S.C.E.; Gnam, J.P.; Kopf, M.; Rathgeber, T.; Woll, A. The Influence of Cortisol, Flow, and Anxiety on Performance in E-Sports: A Field Study. Biomed. Res. Int. 2020, 9651245. [CrossRef] [PubMed]

22. Leff-Gelman, P.; Flores-Ramos, M.; Carrasco, A.E.Á.; Martínez, M.L.; Takashima, M.F.S.; Coronel, F.M.C.; Labonne, B.F.; Dosal, J.A.Z.; Chávez-Peón, P.B.; Morales, S.G.; et al. Cortisol and DHEA-S levels in pregnant women with severe anxiety. BMC Psychiatry 2020, 20, 393. [CrossRef] [PubMed]

23. Tortosa-Martínez, J.; Manchado, C.; Cortell-Tormo, J.M.; Chulvi-Medrano, I. Exercise, the diurnal cycle of cortisol and cognitive impairment in older adults. Neurobiol Stress. 2018, 9, 40-47. [CrossRef] [PubMed]

24. Tsui, A.; Richards, M.; Singh-Manoux, A.; Udeh-Momoh, C.; Davis, D. Longitudinal associations between diurnal cortisol variation and later-life cognitive impairment. Neurology 2020, 94, e133-e141. [CrossRef]

25. Sroykham, W.; Wongsawat, Y. Effects of brain activity, morning salivary cortisol, and emotion regulation on cognitive impairment in elderly people. Medicine 2019, 98, e16114. [CrossRef]

26. Bartlett, D.M.; Cruickshank, T.M.; Hannan, A.J.; Eastwood, P.R.; Lazar, A.S.; Ziman, M.R. Neuroendocrine and neurotrophic signaling in Huntington's disease: Implications for pathogenic mechanisms and treatment strategies. Neurosci. Biobehav. Rev. 2016, 71, 444-454. [CrossRef]

27. Ouanes, S.; Popp, J. High Cortisol and the Risk of Dementia and Alzheimer's Disease: A Review of the Literature. Front. Aging Neurosci. 2019, 11, 43. [CrossRef]

28. Van Cauter, E.; Spiegel, K.; Tasali, E.; Leproult, R. Metabolic consequences of sleep and sleep loss. Sleep Med. 2008, 9, S23-S28. [CrossRef]

29. Leproult, R.; Van Cauter, E. Role of sleep and sleep loss in hormonal release and metabolism. Endocr. Dev. 2010, 17, 11-21. [CrossRef]

30. Elder, G.J.; Wetherell, M.A.; Barclay, N.L.; Ellis, J.G. The cortisol awakening response-applications and implications for sleep medicine. Sleep Med. Rev. 2014, 18, 215-224. [CrossRef]

31. Kritikou, I.; Basta, M.; Vgontzas, A.N.; Pejovic, S.; Fernandez-Mendoza, J.; Liao, D.; Bixler, E.O.; Gaines, J.; Chrousos, G.P. Sleep Apnoea and the Hypothalamic-Pituitary-Adrenal Axis in Men and Women: Effects of Continuous Positive Airway Pressure. Eur. Respir. J. 2016, 47, 531-540. [CrossRef] [PubMed]

32. Buysse, D.J. Sleep and Psychiatric Disorders: A Revisit and Reconceptualization. Can. J. Psychiatry. Rev. Can. Psychiatr. 2010, 55, 401-402. [CrossRef] [PubMed]

33. Staner, L. Comorbidity of Insomnia and Depression. Sleep Med. Rev. 2010, 14, 35-46. [CrossRef] [PubMed]

34. Carnická, Z.; Kollár, B.; Šiarnik, P.; Krížová, L.; Klobucníková, K.; Turcáni, P. Sleep Disorders in Patients with Multiple Sclerosis. J. Clin. Sleep Med. 2015, 11, 553-557. [CrossRef]

35. Cavalcante, A.G.M.; de Bruin, P.F.C.; de Bruin, V.M.S.; Pereira, E.D.B.; Cavalcante, M.M.; Nunes, D.M.; Viana, C.S. Restless Legs Syndrome, Sleep Impairment, and Fatigue in Chronic Obstructive Pulmonary Disease. Sleep Med. 2012, 13, 842-847. [CrossRef]

36. Cuellar, N.G.; Ratcliffe, S.J. A Comparison of Glycemic Control, Sleep, Fatigue, and Depression in Type 2 Diabetes with and without Restless Legs Syndrome. J. Clin. Sleep Med. 2008, 4, 50-56. [CrossRef]

37. Petrowski, K.; Wintermann, G.B.; Schaarschmidt, M.; Bornstein, S.R.; Kirschbaum, C. Blunted Salivary and Plasma Cortisol Response in Patients with Panic Disorder under Psychosocial Stress. Int. J. Psychophysiol. 2013, 88, 35-39. [CrossRef]

38. Bozovic, D.; Racic, M.; Ivkovic, N. Salivary Cortisol Levels as a Biological Marker of Stress Reaction. Med. Arch. 2013, 67, 374-377. [CrossRef]

39. Adam, E.K.; Quinn, M.E.; Tavernier, R.; McQuillan, M.T.; Dahlke, K.A.; Gilbert, K.E. Diurnal cortisol slopes and mental and physical health outcomes: A systematic review and meta-analysis. Psychoneuroendocrinology 2017, 83, 25-41. [CrossRef]

40. Walker, W.H., 2nd; Walton, J.C.; De Vries, A.C.; Nelson, R.J. Circadian rhythm disruption and mental health. Transl. Psychiatry 2020, 10, 28. [CrossRef] 
41. Gow, R.; Thomson, S.; Rieder, M.; Van Uum, S.; Koren, G. An Assessment of Cortisol Analysis in Hair and Its Clinical Applications. Forensic Sci. Int. 2010, 196, 32-37. [CrossRef] [PubMed]

42. Kirschbaum, C.; Tietze, A.; Skoluda, N.; Dettenborn, L. Hair as a Retrospective Calendar of Cortisol Production-Increased Cortisol Incorporation into Hair in the Third Trimester of Pregnancy. Psychoneuroendocrinology 2009, 34, 32-37. [CrossRef] [PubMed]

43. Russell, E.; Koren, G.; Rieder, M.; Van Uum, S. Hair Cortisol as a Biological Marker of Chronic Stress: Current Status, Future Directions and Unanswered Questions. Psychoneuroendocrinology 2012, 37, 589-601. [CrossRef] [PubMed]

44. Ito, N.; Ito, T.; Kromminga, A.; Bettermann, A.; Takigawa, M.; Kees, F.; Straub, R.H.; Paus, R. Human Hair Follicles Display a Functional Equivalent of the Hypothalamic-pituitary-adrenal (HPA) Axis and Synthesize Cortisol. FASEB J. 2005, 19, 1332-1334. [CrossRef]

45. Sharpley, C.F.; Kauter, K.G.; Mcfarlane, J.R. An Initial Exploration of in Vivo Hair Cortisol Responses to a Brief Pain Stressor: Latency, Localization and Independence Effects. Physiol. Res. 2009, 58, 757-761.

46. Henderson, G.L. Mechanisms of Drug Incorporation into Hair. Ther. Drug Monit. 1996, 18, 438-443. [CrossRef]

47. Dettenborn, L.; Tietze, A.; Kirschbaum, C.; Stalder, T. The Assessment of Cortisol in Human Hair: Associations with Sociodemographic Variables and Potential Confounders. Stress 2012, 15, 578-588. [CrossRef]

48. Raul, J.S.; Cirimele, V.; Ludes, B.; Kintz, P. Detection of Physiological Concentrations of Cortisol and Cortisone in Human Hair. Clin. Biochem. 2004, 37, 1105-1111. [CrossRef]

49. Wennig, R. Potential Problems with the Interpretation of Hairanalysis Results. Forensic Sci. Int. 2000, 107, 5-12. [CrossRef]

50. Davenport, M.D.; Tiefenbacher, S.; Lutz, C.K.; Novak, M.A.; Meyer, J.S. Analysis of Endogenous Cortisol Concentrations in the Hair of Rhesus Macaques. Gen. Comp. Endocrinol. 2006, 147, 255-261. [CrossRef]

51. Balagova, L.; Jezova, D. Importance of Methodological Details in the Measurement of Cortisol in Human Hair. Endocr. Regul. 2018, 52, 134-138. [CrossRef] [PubMed]

52. Sauvé, B.; Koren, G.; Walsh, G.; Tokmakejian, S.; Van Uum, S.H.M. Measurement of Cortisol in Human Hair as a Biomarker of Systemic Exposure. Clin. Investig. Med. 2007, 30, 183-191. [CrossRef] [PubMed]

53. Cirimele, V.; Kintz, P.; Dumestre, V.; Goullé, J.P.; Ludes, B. Identification of Ten Corticosteroids in Human Hair by Liquid Chromatography-Ionspray Mass Spectrometry. Forensic Sci. Int. 2000, 107, 381-388. [CrossRef]

54. Yang, H.Z.; Lan, J.; Yan, J.M.; Xue, J.W.; Dail, W.H. A Preliminary Study of Steroid Reproductive Hormones in Human Hair. J. Steroid Biochem. Mol. Biol. 1998, 67, 447-450. [CrossRef]

55. Accorsi, P.A.; Carloni, E.; Valsecchi, P.; Viggiani, R.; Gamberoni, M.; Tamanini, C.; Seren, E. Cortisol Determination in Hair and Faeces from Domestic Cats and Dogs. Gen. Comp. Endocrinol. 2008, 155, 398-402. [CrossRef] [PubMed]

56. Klein, J.; Karaskov, T.; Stevens, B.; Yamada, J.; Koren, G. Hair Cortisol-A Potential Biological Marker for Chronic Stress. Clin. Pharmacol. Ther. 2004, 75, P44. [CrossRef]

57. Slominski, R.; Rovnaghi, C.R.; Anand, K.J. Methodological Considerations for Hair Cortisol Measurements in Children. Ther. Drug Monit. 2015, 37, 812-820. [CrossRef]

58. Russell, E.; Kirschbaum, C.; Laudenslager, M.L.; Stalder, T.; De Rijke, Y.; Van Rossum, E.F.C.; Van Uum, S.; Koren, G. Toward Standardization of Hair Cortisol Measurement: Results of the First International Interlaboratory Round Robin. Ther. Drug Monit. 2015, 37, 71-75. [CrossRef]

59. Loussouarn, G. African Hair Growth Parameters. Br. J. Dermatol. 2001, 145, 294-297. [CrossRef]

60. Salaberger, T.; Millard, M.; Makarem, S.; El Möstl, E.; Grünberger, V.; Krametter-Frötscher, R.; Wittek, T.; Palme, R. Influence of External Factors on Hair Cortisol Concentrations. Gen. Comp. Endocrinol. 2016, 233, 73-78. [CrossRef]

61. Camille Hoffman, M.; Karban, L.V.; Benitez, P.; Goodteacher, A.; Laudenslager, M.L. Chemical Processing and Shampooing Impact Cortisol Measured in Human Hair. Clin. Investig. Med. 2014, 37, 252-257. [CrossRef] [PubMed]

62. Kristensen, S.K.; Larsen, S.C.; Olsen, N.J.; Fahrenkrug, J.; Heitmann, B.L. Hair Dyeing, Hair Washing and Hair Cortisol Concentrations among Women from the Healthy Start Study. Psychoneuroendocrinology 2017, 77, 182-185. [CrossRef] [PubMed]

63. Warnock, F.; Mcelwee, K.; Seo, J.; Mcisaac, S.; Seim, D.; Ramirez-Aponte, T.; Macritchie, K.A.; Young, A.H. Neuropsychiatric Disease and Treatment Measuring Cortisol and DHEA in Fingernails: A Pilot Study. Neuropsychiatr. Dis. Treat. $2010,6,1-7$. [PubMed]

64. Wosu, A.C.; Valdimarsdóttir, U.; Shields, A.E.; Williams, D.R.; Williams, M.A. Correlates of Cortisol in Human Hair: Implications for Epidemiologic Studies on Health Effects of Chronic Stress. Ann. Epidemiol. 2013, 23, 797-811.e2. [CrossRef] [PubMed]

65. Staufenbiel, S.M.; Penninx, B.W.J.H.; de Rijke, Y.B.; van den Akker, E.L.T.; van Rossum, E.F.C. Determinants of Hair Cortisol and Hair Cortisone Concentrations in Adults. Psychoneuroendocrinology 2015, 60, 182-194. [CrossRef]

66. Vanaelst, B.; De Vriendt, T.; Huybrechts, I.; Rinaldi, S.; De Henauw, S. Epidemiological Approaches to Measure Childhood Stress. Paediatr. Perinat. Epidemiol. 2012, 26, 280-297. [CrossRef]

67. van Ockenburg, S.L.; Schenk, H.M.; van der Veen, A.; van Rossum, E.F.C.; Kema, I.P.; Rosmalen, J.G.M. The Relationship between 63 Days of 24-h Urinary Free Cortisol and Hair Cortisol Levels in 10 Healthy Individuals. Psychoneuroendocrinology 2016, 73, 142-147. [CrossRef]

68. Short, S.J.; Stalder, T.; Marceau, K.; Entringer, S.; Moog, N.K.; Shirtcliff, E.A.; Wadhwa, P.D.; Buss, C. Correspondence between Hair Cortisol Concentrations and 30-Day Integrated Daily Salivary and Weekly Urinary Cortisol Measures. Psychoneuroendocrinology 2016, 71, 12-18. [CrossRef] 
69. Izawa, S.; Matsudaira, K.; Miki, K.; Arisaka, M.; Tsuchiya, M. Psychosocial Correlates of Cortisol Levels in Fingernails among Middle-Aged Workers. Stress 2017, 20, 386-389. [CrossRef]

70. Xie, Q.; Gao, W.; Li, J.; Qiao, T.; Jin, J.; Deng, H.; Lu, Z. Correlation of Cortisol in 1-Cm Hair Segment with Salivary Cortisol in Human: Hair Cortisol as an Endogenous Biomarker. Clin. Chem. Lab. Med. 2011, 49, 2013-2019. [CrossRef]

71. D'Anna-Hernandez, K.L.; Ross, R.G.; Natvig, C.L.; Laudenslager, M.L. Hair Cortisol Levels as a Retrospective Marker of Hypothalamic-Pituitary Axis Activity throughout Pregnancy: Comparison to Salivary Cortisol. Physiol. Behav. 2011, 104, 348-353. [CrossRef] [PubMed]

72. Vanaelst, B.; Huybrechts, I.; Bammann, K.; Michels, N.; de Vriendt, T.; Vyncke, K.; Sioen, I.; Iacoviello, L.; Günther, K.; Molnar, D.; et al. Intercorrelations between Serum, Salivary, and Hair Cortisol and Child-Reported Estimates of Stress in Elementary School Girls. Psychophysiology 2012, 49, 1072-1081. [CrossRef] [PubMed]

73. Ouellette, S.J.; Russell, E.; Kryski, K.R.; Sheikh, H.I.; Singh, S.M.; Koren, G.; Hayden, E.P. Hair Cortisol Concentrations in Higherand Lower-Stress Mother-Daughter Dyads: A Pilot Study of Associations and Moderators. Dev. Psychobiol. 2015, 57, 519-534. [CrossRef] [PubMed]

74. Kao, K.; Doan, S.N.; St. John, A.M.; Meyer, J.S.; Tarullo, A.R. Salivary Cortisol Reactivity in Preschoolers Is Associated with Hair Cortisol and Behavioral Problems. Stress 2018, 21, 28-35. [CrossRef]

75. Izawa, S.; Miki, K.; Tsuchiya, M.; Mitani, T.; Midorikawa, T.; Fuchu, T.; Komatsu, T.; Togo, F. Cortisol Level Measurements in Fingernails as a Retrospective Index of Hormone Production. Psychoneuroendocrinology 2015, 54, 24-30. [CrossRef]

76. Buysse, D.J. Sleep Health: Can We Define It? Does It Matter? Sleep 2014, 37, 9-17. [CrossRef]

77. Moore, M. Behavioral Sleep Problems in Children and Adolescents. J. Clin. Psychol. Med. Settings 2012, 19, 77-83. [CrossRef]

78. Léger, D.; Bayon, V. Societal Costs of Insomnia. Sleep Med. Rev. 2010, 14, 379-389. [CrossRef]

79. Cappuccio, F.P.; D’Elia, L.; Strazzullo, P.; Miller, M.A. Quantity and Quality of Sleep and Incidence of Type 2 Diabetes: A Systematic Review and Meta-Analysis. Diabetes Care 2010, 33, 414-420. [CrossRef]

80. Killgore, W.D.S. Effects of Sleep Deprivation on Cognition; Elsevier: Amsterdam, The Netherlands, 2010; Volume 185. [CrossRef]

81. Cunningham, J.E.A.; Jones, S.A.H.; Eskes, G.A.; Rusak, B. Acute Sleep Restriction Has Differential Effects on Components of Attention. Front. Psychiatry 2018, 9, 1-10. [CrossRef]

82. Meier-Ewert, H.K.; Ridker, P.M.; Rifai, N.; Regan, M.M.; Price, N.J.; Dinges, D.F.; Mullington, J.M. Effect of Sleep Loss on C-Reactive Protein, an Inflammatory Marker of Cardiovascular Risk. J. Am. Coll. Cardiol. 2004, 43, 678-683. [CrossRef] [PubMed]

83. Mitchell, J.A.; Rodriguez, D.; Schmitz, K.H.; Audrain-McGovern, J. Sleep Duration and Adolescent Obesity. Pediatrics 2013, 131. [CrossRef] [PubMed]

84. Gangwisch, J.E.; Malaspina, D.; Posner, K.; Babiss, L.A.; Heymsfield, S.B.; Turner, J.B.; Zammit, G.K.; Pickering, T.G. Insomnia and Sleep Duration as Mediators of the Relationship between Depression and Hypertension Incidence. Am. J. Hypertens. 2010, 23, 62-69. [CrossRef] [PubMed]

85. Feliciano, E.M.C.; Quante, M.; Redline, S.; Rifas-Shiman, S.L.; Oken, E.; Taveras, E.M. Objective Sleep Characteristics and Cardiometabolic Health in Young Adolescents. Pediatrics 2018, 142. [CrossRef]

86. Gangwisch, J.E.; Babiss, L.A.; Malaspina, D.; Turner, J.B.; Zammit, G.K.; Posner, K. Earlier Parental Set Bedtimes as a Protective Factor against Depression and Suicidal Ideation. Sleep 2010, 33, 97-106. [CrossRef]

87. Vaughn, B.E.; Elmore-Staton, L.; Shin, N.; El-Sheikh, M. Sleep as a Support for Social Competence, Peer Relations, and Cognitive Functioning in Preschool Children. Behav. Sleep Med. 2015, 13, 92-106. [CrossRef]

88. Liu, X.; Chen, H.; Bo, Q.G.; Fan, F.; Jia, C.X. Poor Sleep Quality and Nightmares Are Associated with Non-Suicidal Self-Injury in Adolescents. Eur. Child. Adolesc. Psychiatry 2017, 26, 271-279. [CrossRef]

89. Cappuccio, F.P.; D’Elia, L.; Strazzullo, P.; Miller, M.A. Sleep Duration and All-Cause Mortality: A Systematic Review and Meta-Analysis of Prospective Studies. Sleep 2010, 33, 585-592. [CrossRef]

90. Åkerstedt, T.; Narusyte, J.; Alexanderson, K. Sleep Duration, Mortality, and Heredity-A Prospective Twin Study. Sleep 2017, 40. [CrossRef]

91. Ranum, B.M.; Wichstrøm, L.; Pallesen, S.; Falch-Madsen, J.; Halse, M.; Steinsbekk, S. Association between Objectively Measured Sleep Duration and Symptoms of Psychiatric Disorders in Middle Childhood. JAMA Netw. Open 2019, 2, e1918281. [CrossRef]

92. Boivin, D.B. Influence of Sleep-Wake and Circadian Rhythm Disturbances in Psychiatric Disorders. J. Psychiatry Neurosci. 2000, 25, 446-458. [PubMed]

93. de Bruin, E.J.; Bögels, S.M.; Oort, F.J.; Meijer, A.M. Improvements of Adolescent Psychopathology after Insomnia Treatment: Results from a Randomized Controlled Trial over 1 Year. J. Child. Psychol. Psychiatry Allied Discip. 2018, 59, 509-522. [CrossRef] [PubMed]

94. Ford, D.E.; Kamerow, D.B. Epidemiologic Study of Sleep Disturbances and Psychiatric Disorders: An Opportunity for Prevention? JAMA J. Am. Med. Assoc. 1989, 262, 1479-1484. [CrossRef]

95. Hambrick, E.P.; Rubens, S.L.; Brawner, T.W.; Taussig, H.N. Do Sleep Problems Mediate the Link between Adverse Childhood Experiences and Delinquency in Preadolescent Children in Foster Care? J. Child. Psychol. Psychiatry Allied Discip. 2018, 59, 140-149. [CrossRef]

96. Carvalho Bos, S.; Gomes, A.; Clemente, V.; Marques, M.; Pereira, A.T.; Maia, B.; Soares, M.J.; Cabral, A.S.; Macedo, A.; Gozal, D.; et al. Sleep and Behavioral/Emotional Problems in Children: A Population-Based Study. Sleep Med. 2009, 10, 66-74. [CrossRef] 
97. Harvey, A.G.; Murray, G.; Chandler, R.A.; Soehner, A. Sleep Disturbance as Transdiagnostic: Consideration of Neurobiological Mechanisms. Clin. Psychol. Rev. 2011, 31, 225-235. [CrossRef]

98. Murray, C.B.; Murphy, L.K.; Palermo, T.M.; Clarke, G.M. Pain and Sleep-Wake Disturbances in Adolescents With Depressive Disorders. J. Clin. Child. Adolesc. Psychol. 2012, 41, 482-490. [CrossRef]

99. Wong, M.M.; Brower, K.J.; Zucker, R.A. Sleep Problems, Suicidal Ideation, and Self-Harm Behaviors in Adolescence. J. Psychiatr. Res. 2011, 45, 505-511. [CrossRef]

100. Buckley, T.M.; Schatzberg, A.F. Review: On the Interactions of the Hypothalamic-Pituitary-Adrenal (HPA) Axis and Sleep: Normal HPA Axis Activity and Circadian Rhythm, Exemplary Sleep Disorders. J. Clin. Endocrinol. Metab. 2005, 90, 3106-3114. [CrossRef]

101. Steiger, A. Sleep and the Hypothalamo-Pituitary-Adrenocortical System. Sleep Med. Rev. 2002, 6, 125-138. [CrossRef]

102. Vgontzas, A.N.; Chrousos, G.P. Sleep, the Hypothalamic-Pituitary-Adrenal Axis, and Cytokines: Multiple Interactions and Disturbances in Sleep Disorders. Endocrinol. Metab. Clin. N. Am. 2002, 31, 15-36. [CrossRef]

103. Meerlo, P.; Sgoifo, A.; Suchecki, D. Restricted and Disrupted Sleep: Effects on Autonomic Function, Neuroendocrine Stress Systems and Stress Responsivity. Sleep Med. Rev. 2008, 12, 197-210. [CrossRef] [PubMed]

104. Marcella, B.; Leproult, R.; Van Cauter, E. Impact of Sleep and Its Disturbances on Hypothalamo-Pituitary-Adrenal Axis Activity. Int. J. Endocrinol. 2010, 2010. [CrossRef]

105. Hori, H.; Teraishi, T.; Sasayama, D.; Ozeki, Y.; Matsuo, J.; Kawamoto, Y.; Kinoshita, Y.; Hattori, K.; Higuchi, T.; Kunugi, H. Poor Sleep Is Associated with Exaggerated Cortisol Response to the Combined Dexamethasone/CRH Test in a Non-Clinical Population. J. Psychiatr. Res. 2011, 45, 1257-1263. [CrossRef]

106. Räikkönen, K.; Matthews, K.A.; Pesonen, A.K.; Pyhälä, R.; Paavonen, E.J.; Feldt, K.; Jones, A.; Phillips, D.I.W.; Seckl, J.R.; Heinonen, K.; et al. Poor Sleep and Altered Hypothalamic-Pituitary-Adrenocortical and Sympatho-Adrenal-Medullary System Activity in Children. J. Clin. Endocrinol. Metab. 2010, 95, 2254-2261. [CrossRef]

107. McEwen, B.S. Protection and Damage from Acute and Chronic Stress: Allostasis and Allostatic Overload and Relevance to the Pathophysiology of Psychiatric Disorders. Ann. N. Y. Acad. Sci. 2004, 1032, 1-7. [CrossRef]

108. Chrousos, G.P.; Gold, P.W. The Concepts of Stress and Stress System Disorders: Overview of Physical and Behavioral Homeostasis. JAMA J. Am. Med. Assoc. 1992, 267, 1244-1252. [CrossRef]

109. Minkel, J.; Moreta, M.; Muto, J.; Htaik, O.; Jones, C.; Basner, M.; Dinges, D. Sleep Deprivation Potentiates HPA Axis Stress Reactivity in Healthy Adults. Health Psychol. 2014, 33, 1430-1434. [CrossRef]

110. Lee, D.Y.; Kim, E.; Choi, M.H. Technical and Clinical Aspects of Cortisol as a Biochemical Marker of Chronic Stress. BMB Rep. 2015, 48, 209-216. [CrossRef]

111. Durán-Carabali, L.E.; Henao-Pacheco, M.L.; González-Clavijo, A.M.; Dueñas, Z. Salivary Alpha Amylase and Cortisol Levels as Stress Biomarkers in Children with Cerebral Palsy and Their Association with a Physical Therapy Program. Res. Dev. Disabil. 2021, 108, 103807. [CrossRef]

112. Stalder, T.; Kirschbaum, C. Analysis of Cortisol in Hair-State of the Art and Future Directions. Brain. Behav. Immun. 2012, 26, 1019-1029. [CrossRef] [PubMed]

113. Stalder, T.; Steudte-Schmiedgen, S.; Alexander, N.; Klucken, T.; Vater, A.; Wichmann, S.; Kirschbaum, C.; Miller, R. Stress-Related and Basic Determinants of Hair Cortisol in Humans: A Meta-Analysis; Elsevier: Amsterdam, The Netherlands, 2017 ; Volume 77. [CrossRef]

114. Buckley, T.M.; Schatzberg, A.F. Aging and the Role of the HPA Axis and Rhythm in Sleep and Memory-Consolidation. Am. J. Geriatr. Psychiatry 2005, 13, 344-352. [CrossRef] [PubMed]

115. Koolhaas, J.M.; De Boer, S.F.; De Ruitter, A.J.H.; Meerlo, P.; Sgoifo, A. Social Stress in Rats and Mice. Acta Physiol. Scand. Suppl. 1997, 161, 69-72.

116. Meerlo, P.; Koehl, M.; Van Der Borght, K.; Turek, F.W. Sleep Restriction Alters the Hypothalamic-Pituitary-Adrenal Response to Stress. J. Neuroendocrinol. 2002, 14, 397-402. [CrossRef]

117. Germain, A.; Buysse, D.J.; Ombao, H.; Kupfer, D.J.; Hall, M. Psychophysiological Reactivity and Coping Styles Influence the Effects of Acute Stress Exposure on Rapid Eye Movement Sleep. Psychosom. Med. 2003, 65, 857-864. [CrossRef]

118. Kim, E.J.; Dimsdale, J.E. The Effect of Psychosocial Stress on Sleep: A Review of Polysomnographic Evidence. Behav. Sleep Med. 2007, 5, 256-278. [CrossRef]

119. van Dalfsen, J.H.; Markus, C.R. The Influence of Sleep on Human Hypothalamic-Pituitary-Adrenal (HPA) Axis Reactivity: A Systematic Review. Sleep Med. Rev. 2018, 39, 187-194. [CrossRef]

120. Cartwright, R.D.; Wood, E. Adjustment Disorders of Sleep: The Sleep Effects of a Major Stressful Event and Its Resolution. Psychiatry Res. 1991, 39, 199-209. [CrossRef]

121. Armon, G.; Shirom, A.; Shapira, I.; Melamed, S. On the Nature of Burnout-Insomnia Relationships: A Prospective Study of Employed Adults. J. Psychosom. Res. 2008, 65, 5-12. [CrossRef]

122. Grossi, G.; Perski, A.; Evengård, B.; Blomkvist, V.; Orth-Gomér, K. Physiological Correlates of Burnout among Women. J. Psychosom. Res. 2003, 55, 309-316. [CrossRef]

123. Söderström, M.; Ekstedt, M.; Åkerstedt, T.; Nilsson, J.; Axelsson, J. Sleep and Sleepiness in Young Individuals with High Burnout Scores. Sleep 2004, 27, 1369-1377. [CrossRef] [PubMed] 
124. Wang, C.; Dai, J.; Li, J. Mediating Effects of Hair Cortisol on the Mutual Association of Job Burnout and Insomnia: A Retrospective Exploratory Study. J. Psychiatr. Res. 2019, 117, 62-67. [CrossRef] [PubMed]

125. Strahler, J.; Skoluda, N.; Kappert, M.B.; Nater, U.M. Simultaneous Measurement of Salivary Cortisol and Alpha-Amylase: Application and Recommendations. Neurosci. Biobehav. Rev. 2017, 83, 657-677. [CrossRef] [PubMed]

126. Nicolson, N.A.; Van Diest, R. Salivary Cortisol Patterns in Vital Exhaustion. J. Psychosom. Res. 2000, 49, 335-342. [CrossRef]

127. Huang, T.; Poole, E.M.; Vetter, C.; Rexrode, K.M.; Kubzansky, L.D.; Schernhammer, E.; Rohleder, N.; Hu, F.B.; Redline, S.; Tworoger, S.S. Habitual Sleep Quality and Diurnal Rhythms of Salivary Cortisol and Dehydroepiandrosterone in Postmenopausal Women. Psychoneuroendocrinology 2017, 84, 172-180. [CrossRef]

128. Späth-Schwalbe, E.; Gofferje, M.; Kern, W.; Born, J.; Fehm, H.L. Sleep Disruption Alters Nocturnal ACTH and Cortisol Secretory Patterns. Biol. Psychiatry 1991, 29, 575-584. [CrossRef]

129. Steiger, A.; Holsboer, F. Nocturnal Secretion of Prolactin and Cortisol and the Sleep EEG in Patients with Major Endogenous Depression during an Acute Episode and after Full Remission. Psychiatry Res. 1997, 72, 81-88. [CrossRef]

130. Abell, J.G.; Shipley, M.J.; Ferrie, J.E.; Kivimäki, M.; Kumari, M. Recurrent Short Sleep, Chronic Insomnia Symptoms and Salivary Cortisol: A 10-Year Follow-up in the Whitehall II Study. Psychoneuroendocrinology 2016, 68, 91-99. [CrossRef]

131. Lim, G.Y.; Jang, T.W.; Sim, C.S.; Ahn, Y.S.; Jeong, K.S. Comparison of Cortisol Level by Shift Cycle in Korean Firefighters. Int. J. Environ. Res. Public Health 2020, 17, 4760. [CrossRef]

132. Janssens, H.; Braeckman, L.; Vlerick, P.; Van de Ven, B.; De Clercq, B.; Clays, E. The Relation between Social Capital and Burnout: A Longitudinal Study. Int. Arch. Occup. Environ. Health 2018, 91, 1001-1009. [CrossRef]

133. Zhang, Y.; Shen, J.; Zhou, Z.; Sang, L.; Zhuang, X.; Chu, M.; Tian, T.; Xiao, J.; Lian, Y. Relationships among Shift Work, Hair Cortisol Concentration and Sleep Disorders: A Cross-Sectional Study in China. BMJ Open 2020, 10. [CrossRef] [PubMed]

134. Colledge, F.; Brand, S.; Zimmerer, S.; Pühse, U.; Holsboer-Trachsler, E.; Gerber, M. In Individuals Following Aneurysmal Subarachnoid Haemorrhage, Hair Cortisol Concentrations Are Higher and More Strongly Associated with Psychological Functioning and Sleep Complaints than in Healthy Controls. Neuropsychobiology 2017, 75, 12-20. [CrossRef] [PubMed]

135. Feller, S.; Vigl, M.; Bergmann, M.M.; Boeing, H.; Kirschbaum, C.; Stalder, T. Predictors of Hair Cortisol Concentrations in Older Adults. Psychoneuroendocrinology 2014, 39, 132-140. [CrossRef] [PubMed]

136. Lanfear, J.H.; Voegel, C.D.; Binz, T.M.; Paul, R.A. Hair Cortisol Measurement in Older Adults: Influence of Demographic and Physiological Factors and Correlation with Perceived Stress. Steroids 2020, 163, 108712. [CrossRef] [PubMed]

137. Fries, E.; Dettenborn, L.; Kirschbaum, C. The Cortisol Awakening Response (CAR): Facts and Future Directions. Int. J. Psychophysiol. 2009, 72, 67-73. [CrossRef]

138. Wüst, S.; Wolf, J.; Hellhammer, D.H.; Federenko, I.; Schommer, N.; Kirschbaum, C. The Cortisol Awakening Response-Normal Values and Confounds. Noise Health 2000, 2, 79-88.

139. Backhaus, J.; Junghanns, K.; Hohagen, F. Sleep Disturbances Are Correlated with Decreased Morning Awakening Salivary Cortisol. Psychoneuroendocrinology 2004, 29, 1184-1191. [CrossRef]

140. Holder, M.K.; Blaustein, J.D. Puberty and Adolescence as a Time of Vulnerability to Stressors that Alter Neurobehavioral Processes. Front. Neuroendocrinol. 2014, 35, 89-110. [CrossRef]

141. Steinberg, L. Cognitive and Affective Development in Adolescence. Trends Cogn. Sci. 2005, 9, 69-74. [CrossRef]

142. Gregory, A.M.; Sadeh, A. Annual Research Review: Sleep Problems in Childhood Psychiatric Disorders-A Review of the Latest Science. J. Child. Psychol. Psychiatry Allied Discip. 2016, 57, 296-317. [CrossRef]

143. Reidy, B.L.; Raposa, E.B.; Brennan, P.A.; Hammen, C.L.; Najman, J.M.; Johnson, K.C. Prospective Associations between Chronic Youth Sleep Problems and Young Adult Health. Sleep Health 2016, 2, 69-74. [CrossRef] [PubMed]

144. Owens, J.A.; Spirito, A.; McGuinn, M.; Nobile, C. Sleep Habits and Sleep Disturbance in Elementary School-Aged Children. J. Dev. Behav. Pediatr. 2000, 21, 27-36. [CrossRef]

145. Liu, X.; Liu, L.; Owen, J.A.; Kaplan, D.L. Sleep Patterns and Sleep Problems among Schoolchildren in the United States and China. Pediatrics 2005, 115, 241-249. [CrossRef]

146. Pagel, J.F.; Forister, N.; Kwiatkowki, C. Adolescent Sleep Disturbance and School Performance: The Confounding Variable of Socioeconomics. J. Clin. Sleep Med. 2007, 3, 19-23.

147. Magee, C.A.; Gordon, R.; Caputi, P. Distinct Developmental Trends in Sleep Duration during Early Childhood. Pediatrics 2014, 133, 1561-1567. [CrossRef]

148. Spruyt, K.; Alaribe, C.U.; Nwabara, O.U. To Sleep or Not to Sleep: A Repeated Daily Challenge for African American Children. CNS Neurosci. Ther. 2015, 21, 23-31. [CrossRef]

149. O'Brien, E.M.; Mindell, J.A. Sleep and Risk-Taking Behavior in Adolescents. Behav. Sleep Med. 2005, 3, 113-133. [CrossRef]

150. Dewald, J.F.; Meijer, A.M.; Oort, F.J.; Kerkhof, G.A.; Bögels, S.M. The Influence of Sleep Quality, Sleep Duration and Sleepiness on School Performance in Children and Adolescents: A Meta-Analytic Review. Sleep Med. Rev. 2010, 14, 179-189. [CrossRef]

151. Stalder, T.; Bäumler, D.; Miller, R.; Alexander, N.; Kliegel, M.; Kirschbaum, C. The Cortisol Awakening Response in Infants: Ontogeny and Associations with Development-Related Variables. Psychoneuroendocrinology 2013, 38, 552-559. [CrossRef]

152. Gribbin, C.E.; Watamura, S.E.; Cairns, A.; Harsh, J.R.; Lebourgeois, M.K. The Cortisol Awakening Response (CAR) in 2- to 4-Year-Old Children: Effects of Acute Nighttime Sleep Restriction, Wake Time, and Daytime Napping. Dev. Psychobiol. 2012, 54, 412-422. [CrossRef] 
153. Fernandez-Mendoza, J.; Vgontzas, A.N.; Calhoun, S.L.; Vgontzas, A.; Tsaoussoglou, M.; Gaines, J.; Liao, D.; Chrousos, G.P.; Bixler, E.O. Insomnia Symptoms, Objective Sleep Duration and Hypothalamic-Pituitary-Adrenal Activity in Children. Eur. J. Clin. Invest. 2014, 44, 493-500. [CrossRef] [PubMed]

154. Pesonen, A.K.; Martikainen, S.; Kajantie, E.; Heinonen, K.; Wehkalampi, K.; Lahti, J.; Strandberg, T.; Räikkönen, K. The Associations between Adolescent Sleep, Diurnal Cortisol Patterns and Cortisol Reactivity to Dexamethasone Suppression Test. Psychoneuroendocrinology 2014, 49, 150-160. [CrossRef] [PubMed]

155. Hatzinger, M.; Brand, S.; Perren, S.; Von Wyl, A.; Stadelmann, S.; von Klitzing, K.; Holsboer-Trachsler, E. In Pre-School Children, Sleep Objectively Assessed via Sleep-EEGs Remains Stable over 12 Months and Is Related to Psychological Functioning, but Not to Cortisol Secretion. J. Psychiatr. Res. 2013, 47, 1809-1814. [CrossRef]

156. Lemola, S.; Perkinson-Gloor, N.; Hagmann-von Arx, P.; Brand, S.; Holsboer-Trachsler, E.; Grob, A.; Weber, P. Morning Cortisol Secretion in School-Age Children Is Related to the Sleep Pattern of the Preceding Night. Psychoneuroendocrinology 2015, 52, 297-301. [CrossRef] [PubMed]

157. Perkinson-Gloor, N.; Hagmann-von Arx, P.; Brand, S.; Holsboer-Trachsler, E.; Grob, A.; Weber, P.; Lemola, S. The Role of Sleep and the Hypothalamic-Pituitary-Adrenal Axis for Behavioral and Emotional Problems in Very Preterm Children during Middle Childhood. J. Psychiatr. Res. 2015, 60, 141-147. [CrossRef]

158. Brooks, E.; Canal, M.M. Development of Circadian Rhythms: Role of Postnatal Light Environment. Neurosci. Biobehav. Rev. 2013, 37, 551-560. [CrossRef]

159. Björkqvist, J.; Paavonen, J.; Andersson, S.; Pesonen, A.K.; Lahti, J.; Heinonen, K.; Eriksson, J.; Räikkönen, K.; Hovi, P.; Kajantie, E.; et al. Advanced Sleep-Wake Rhythm in Adults Born Prematurely: Confirmation by Actigraphy-Based Assessment in the Helsinki Study of Very Low Birth Weight Adults. Sleep Med. 2014, 15, 1101-1106. [CrossRef]

160. Strang-Karlsson, S.; Kajantie, E.; Pesonen, A.K.; Rikknen, K.; Hovi, P.; Lahti, J.; Heinonen, K.; Jrvenp, A.L.; Eriksson, J.G.; Andersson, S.; et al. Morningness Propensity in Young Adults Born Prematurely: The Helsinki Study of Very Low Birth Weight Adults. Chronobiol. Int. 2010, 27, 1829-1842. [CrossRef]

161. Hibbs, A.M.; Storfer-Isser, A.; Rosen, C.; Ievers-Landis, C.E.; Taveras, E.M.; Redline, S. Advanced Sleep Phase in Adolescents Born Preterm. Behav. Sleep Med. 2014, 12, 412-424. [CrossRef]

162. Karlén, J.; Ludvigsson, J.; Hedmark, M.; Faresjö, Å.; Theodorsson, E.; Faresjö, T. Early Psychosocial Exposures, Hair Cortisol Levels, and Disease Risk. Pediatrics 2015, 135, e1450-e1457. [CrossRef]

163. Flom, M.; St John, A.M.; Meyer, J.S.; Tarullo, A.R. Infant Hair Cortisol: Associations with Salivary Cortisol \& Environmental Context. Dev. Psychobiol. 2017, 59, 26-38. [CrossRef]

164. Eythorsdottir, D.Y.; Frederiksen, P.; Larsen, S.C.; Olsen, N.J.; Heitmann, B.L. Associations between Objective Measures of Physical Activity, Sleep and Stress Levels among Preschool Children. BMC Pediatr. 2020, 20, 1-7. [CrossRef]

165. Kiel, E.J.; Hummel, A.C.; Luebbe, A.M. Cortisol Secretion and Change in Sleep Problems in Early Childhood: Moderation by Maternal Overcontrol. Biol. Psychol. 2015, 107, 52-60. [CrossRef] [PubMed]

166. Scher, A.; Hall, W.A.; Zaidman-Zait, A.; Weinberg, J. Sleep Quality, Cortisol Levels, and Behavioral Regulation in Toddlers. Dev. Psychobiol. 2010, 52, 44-53. [CrossRef] [PubMed]

167. Leproult, R.; Copinschi, G.; Buxton, O.; Van Cauter, E. Sleep Loss Results in an Elevation of Cortisol Levels the next Evening. Sleep 1997, 20, 865-870. [CrossRef]

168. Spiegel, K.; Leproult, R.; Van Cauter, E. Impact of Sleep Debt on Metabolic and Endocrine Function. Lancet 1999, 354, 1435-1439. [CrossRef]

169. Rodenbeck, A.; Hajak, G. Neuroendocrine Dysregulation in Primary Insomnia. Rev. Neurol. 2001, 157, 57-61.

170. Rodenbeck, A.; Huether, G.; Rüther, E.; Hajak, G. Interactions between Evening and Nocturnal Cortisol Secretion and Sleep Parameters in Patients with Severe Chronic Primary Insomnia. Neurosci. Lett. 2002, 324, 159-163. [CrossRef]

171. Holsboer, F.; von Bardeleben, U.; Steiger, A. Effects of Intravenous Corticotropin-Releasing Hormone upon Sleep-Related Growth Hormone Surge and Sleep EEG in Man. Neuroendocrinology 1988, 48, 32-38. [CrossRef] 